\title{
ROLE OF ORAL GABAPENTIN IN ATTENUATING CARDIOVASCULAR RESPONSE TO LARYNGOSCOPY AND TRACHEAL INTUBATION.
}

1. MBBS, FCPS

Assistant Professor Anesthesia

Faisalabad Medical University/

Allied Hospital, Faisalabad.

2. MBBS, FCPS

Assistant Professor Anesthesia Independent Medical College, Faisalabad.

3. MBBS, FCPS

Consultant and HOD Anesthesia

Zabidi Eye Complex, Makkah KSA

4. MBBS, MPH

Associate Professor Community Medicine

Independent Medical College,

Faisalabad.

Correspondence Address:

Dr. Mohsin Riaz Askri

Anesthesia

Faisalabad Medical University/

Allied Hospital, Faisalabad.

mohsinriaz46@yahoo.com

Article received on:

28/11/2019

Accepted for publication:

20/02/2020

\begin{abstract}
Mohsin Riaz Askri', Shumyala Maqbool ${ }^{2}$, Kausar Abbas Shah ${ }^{3}$, Shahbaz Ahmad
\end{abstract}
ABSTRACT... Objectives: To determine the role of $800 \mathrm{mg}$ oral gabapentin in attenuating cardiovascular response to laryngoscopy and tracheal intubation. Study Design: Double Blind Randomized Control Trial. Setting: Independent University Hospital/Independent Medical College, Faisalabad, Pakistan. Period: Six months from January $1^{\text {st }} 2019$ to June $30^{\text {th }} 2019$. Material \& Methods: This study included 60 patients which were divided into two equal groups. $800 \mathrm{mg}$ oral gabapentin was given to group I while capsule placebo was administrated to group II patients in pre-operative area one hour prior to surgery. Heart rate, systolic, diastolic and mean arterial blood pressure were taken after induction of anesthesia at base line and then $1,2,3,4,5,10$ and 15 minutes after endotracheal intubation. SPSS version 11 was used to analyze the data. Heart rate systolic, diastolic and mean arterial blood pressure were dependent variables while placebo and gabapentin were independent variables. Results: Out of total 60 patients there were $36(60 \%)$ males and $24(40 \%)$ females. In group I mean age was 37.1 while in group II it was 36.3. As compare to group II there was decreased cardiovascular response in group I. There was a significant decrease in systolic blood pressure at 1,2 and 10 minutes; diastolic blood pressure at 3 minutes; heart rate at 10 and 15 minutes and mean arterial blood pressure at 3 minutes after induction in group I. Conclusion: Cardiovascular response to laryngoscopy and intubation is significantly reduced with oral gabapentin.

Key words: Cardiovascular Response, Gabapentin, Laryngoscopy and Endotracheal Intubation.

Article Citation: Askri MR, Maqbool S, Shah KA, Ahmad S. Role of oral gabapentin in attenuating cardiovascular response to laryngoscopy and tracheal intubation. Professional Med J 2020; 27(7):1470-1475.

DOI: 10.29309/TPMJ/2020.27.07.4373

\section{INTRODUCTION}

Endotracheal tube (ETT) is passed for airway maintenance and protection from aspiration of gastric contents. ${ }^{1}$ This endotracheal intubation needs laryngoscopy to visualize vocal cords so that ETT can be placed in right position.

The response of the body to this laryngoscopy and tracheal intubation is stress response, which may include secretion of stress hormones e.g. catecholamines, glucagon, and antidiuretic hormone. ${ }^{2}$ There is a significant increase in intracranial pressure, intraocular pressure, heart rate and blood pressure caused by stress hormone. ${ }^{3}$ Such change in B.P and HR is called cardiovascular response or presser response.

Cardiovascular response is well tolerated by young children and adults not having any cardiac problem, but this response can be catastrophic in cardiac patients, geriatric patients ${ }^{4}$ and very sick patients, who have decreased cardiac reserves, because of increase in myocardial oxygen demand which is not properly met in compromised patients. This is due to increase in blood pressure and heart rate which may result in myocardial ischemia, infarction, and cardiac failure, depending upon the severity of the disease. The cardiovascular response can be minimized mainly by two strategies; one is avoiding the endotracheal intubation and laryngoscopy by using supraglottic airways, secondly when intubation is indispensable, to use different drugs which can help to decrease the pressor response. 
The most commonly used equipment's include, oropharyngeal airway ${ }^{5}$, laryngeal mask airway ${ }^{6}$, laryngeal tube ${ }^{7}$, and I Gel. ${ }^{8}$

Many drugs have been used to attenuate the cardiovascular response to tracheal intubation and laryngoscopy. Lidocaine either sprayed directly on the vocal cords or given intravenously not only decreases the sensitivity of upper airway but also attenuate the heart rate and blood pressure changes during laryngoscopy. ${ }^{9}$

There is increase in anesthetic depth and decrease in cardiovascular response to laryngoscopy and intubation with ultra-short acting opioids like fentanyl, ramifentanil and sufentanil. ${ }^{10}$

Beta blockers are also used to decreased the laryngoscopy and tracheal effects on cardiovascular system. Among the beta blockers the ultra-short acting esmolol is used frequently due to its cardio selective adrenergic receptor blocking properties. ${ }^{11,12}$

There are recent recommendations on the role of gabapentin to attenuate the cardiovascular effects of laryngoscopy and intubation. ${ }^{13}$ With combination of other anti-seizure drugs gabapentin was recommended to be used for treatment of partial seizures by FDA in $1994 .{ }^{14}$ It was recommended to be used in the treatment of nerve related pain, post herpetic neuralgia ${ }^{15}$ and other painful neuropathies in $2002 .{ }^{16}$ It also has limited role in the treatment of anxiety, depression, and restless leg syndrome.

Gabapentin, anticonvulsant is also effective in neuropathic pain management. It is used for decreasing opiod requirement postoperatively and treating acute post-operative pain in human studies. We conducted this study to evaluate the effect of gabapentin in attenuating cardiovascular response to laryngoscopy and intubation in patients undergoing elective surgery.

\section{MATERIAL \& METHODS}

This randomized controlled trial was conducted at Independent University Hospital Faisalabad over six months from January $1^{\text {st }} 2019$ to June $30^{\text {th }}$ 2019. Sample size of sixty cases (30 in each group) was calculated with 80 percent power of test and 9 percent confidence interval. After taking informed consent, non-probability consecutive sampling was done in sixty patients. The inclusion criteria were patient of 20-30 years of age, ASA I\&II undergoing elective surgical procedures. Patients in whom laryngoscopy time exceeds fifteen seconds, pregnant patients and patients known case of hypertension and ischemic heart disease were excluded.

Demographic data, ASA status and information regarding surgical procedure were recorded. One hour before induction of anaesthesia $800 \mathrm{mg}$ oral gabapentin was given to group I and placebo capsule was given to group II.

Every patient was premedicated with midazolam 2mg I/V. After standard induction with inj. Propofol2mg / kg, inj. Rocuronium $0.6 \mathrm{mg} / \mathrm{kg}$ and waiting for 2 minutes patient were intubated after direct laryngoscopy. Anaesthesia was maintained with sevoflurane.

Study variables, pulse and non-invasive blood pressure were taken from the monitor at 1,2,3,4,5, 10 and 15 minutes. A designed proforma was used to record the data of study variables and demographic data like name, age, sex.

SPSS version 11 was used to analyse the data. Standard deviation and mean were used for age description while sex was described in percentage. Paired t-test was used to compare systolic, diastolic and mean blood pressures. P-value $<0.05$ was considered significant.

\section{RESULTS}




\begin{tabular}{|l|l|c|c|c|}
\hline \multirow{2}{*}{ Gender } & \multirow{2}{*}{ Count/Percentage } & \multicolumn{2}{|c|}{ Study Groups } & \multicolumn{2}{c|}{ Total } \\
\hline \multirow{2}{*}{ Male } & Count & Gabapentin & Placebo & 36 \\
\cline { 2 - 5 } & $\%$ & 16 & 20 & 60.0 \\
\hline \multirow{2}{*}{ Female } & Count & 57.7 & 63.3 & 24 \\
\hline \multirow{2}{*}{ Total } & $\%$ & 14 & 10 & 40.0 \\
\hline & Count & 43.33 & 36.67 & 60 \\
\hline
\end{tabular}

Table-I. Sex distribution of the subject under study

\begin{tabular}{|l|c|c|c|}
\hline \multicolumn{1}{|c|}{ Study Groups } & N & Mean & Std. Deviation \\
\hline Gabapentin & 30 & 38 & 12 \\
\hline Placebo & 30 & 35 & 14 \\
\hline
\end{tabular}

Table-II. Comparison of mean age of the subject under study

\begin{tabular}{|c|c|c|c|c|c|}
\hline \multirow{2}{*}{$\begin{array}{c}\text { Hear Rate Observation } \\
\text { Baseline and After } \\
\text { Intubation }\end{array}$} & \multicolumn{2}{|c|}{$\begin{array}{c}\text { I (Gabapentin) } \\
\mathrm{N}=\mathbf{3 0}\end{array}$} & \multicolumn{2}{|c|}{$\begin{array}{c}\text { II (Placebo) } \\
\quad \mathrm{N}=\mathbf{3 0}\end{array}$} & \multirow{2}{*}{$\begin{array}{c}\text { P-Value for } \\
\text { t-test }\end{array}$} \\
\hline & Mean & $\begin{array}{l}\text { Standard } \\
\text { Deviation }\end{array}$ & Mean & $\begin{array}{l}\text { Standard } \\
\text { Deviation }\end{array}$ & \\
\hline Baseline & 85 & 10 & 90 & 16 & $0.188(>0.05)$ \\
\hline 1-minute postintubation & 102 & 14 & 106 & 12 & $0.077(>0.05)$ \\
\hline 2-minute postintubation & 105 & 14 & 108 & 15 & $0.198(>0.05)$ \\
\hline 3-minute postintubation & 100 & 15 & 107 & 14 & $0.242(>0.05)$ \\
\hline 4-minute postintubation & 100 & 13 & 105 & 18 & $0.231(>0.05)$ \\
\hline 5-minute postintubation & 94 & 14 & 105 & 19 & $0.125(>0.05)$ \\
\hline 10-minute postintubation & 92 & 15 & 100 & 18 & $0.041(<0.05)$ \\
\hline 15-minute postintubation & 88 & 14 & 98 & 16 & $0.002(<0.05)$ \\
\hline
\end{tabular}

Table-III. Comparison of mean heart rates in series of observations before and after induction with Gabapentin and placebo as pre-anesthetic drugs.

\begin{tabular}{|l|c|c|c|c|c|}
\hline \multirow{2}{*}{$\begin{array}{c}\text { Systolic BP Observation } \\
\text { Baseline and After Intubation }\end{array}$} & \multicolumn{2}{|c|}{$\begin{array}{c}\text { I (Gabapentin) } \\
\text { N=30 }\end{array}$} & \multicolumn{2}{c|}{$\begin{array}{c}\text { II (Placebo) } \\
\text { N=30 }\end{array}$} & $\begin{array}{c}\text { P-Value for } \\
\text { t-test }\end{array}$ \\
\cline { 2 - 5 } & Mean & $\begin{array}{c}\text { Standard } \\
\text { Deviation }\end{array}$ & Mean & $\begin{array}{c}\text { Standard } \\
\text { Deviation }\end{array}$ & \\
\hline Baseline & 122 & 12 & 125 & 13 & $0.302(\mathrm{P}>0.05)$ \\
\hline 1-minute after intubation & 135 & 22 & 148 & 23 & $0.026(\mathrm{P}<0.05)$ \\
\hline 2- minute after intubation & 118 & 21 & 134 & 24 & $0.01(\mathrm{P}<0.05)$ \\
\hline 3-minute after intubation & 119 & 16 & 125 & 21 & $0.234(\mathrm{P}>0.05)$ \\
\hline 4-minute after intubation & 115 & 14 & 118 & 13 & $0.156(\mathrm{P}>0.05)$ \\
\hline 5-minute after intubation & 107 & 13 & 115 & 11 & $0.101(\mathrm{P}>0.05)$ \\
\hline 10-minute after intubation & 106 & 12 & 118 & 16 & $0.008(\mathrm{P}<0.05)$ \\
\hline 15-minute after intubation & 106 & 13 & 115 & 13 & $0.007(\mathrm{P}<0.05)$ \\
\hline
\end{tabular}

Table-IV. Comparison of mean systolic BP before and after induction with Gabapentin and placebo as preanesthetic drugs. 


\begin{tabular}{|c|c|c|c|c|c|}
\hline \multirow{2}{*}{$\begin{array}{l}\text { Diastolic BP Observation } \\
\text { Baseline and After Intubation }\end{array}$} & \multicolumn{2}{|c|}{$\begin{array}{l}\text { I (Gabapentin) } \\
\quad \mathrm{N}=30\end{array}$} & \multicolumn{2}{|c|}{$\begin{array}{l}\text { II (Placebo) } \\
\quad \mathrm{N}=\mathbf{3 0}\end{array}$} & \multirow{2}{*}{$\begin{array}{l}\text { P-Value for } \\
\text { t-test }\end{array}$} \\
\hline & Mean & $\begin{array}{l}\text { Standard } \\
\text { Deviation }\end{array}$ & Mean & $\begin{array}{l}\text { Standard } \\
\text { Deviation }\end{array}$ & \\
\hline Baseline & 77 & 12 & 78 & 11 & $0.946(>0.05)$ \\
\hline 1-minute after intubation & 86 & 19 & 95 & 19 & $0.187(>0.05)$ \\
\hline 2- minute after intubation & 72 & 16 & 84 & 17 & $0.018(>0.05)$ \\
\hline 3-minute after intubation & 69 & 15 & 75 & 17 & $0.187(>0.05)$ \\
\hline 4-minute after intubation & 70 & 13 & 70 & 14 & $0.590(>0.05)$ \\
\hline 5-minute after intubation & 62 & 12 & 66 & 10 & $0.480(>0.05)$ \\
\hline 10-minute after intubation & 62 & 11 & 69 & 13 & $0.081(>0.05)$ \\
\hline 15-minute after intubation & 60 & 12 & 66 & 13 & $0.075(>0.05)$ \\
\hline \multicolumn{6}{|c|}{$\begin{array}{l}\text { Table-V. Comparison of mean diastolic BP in series of observation before and after induction with Gabapentin anc } \\
\text { placebo as preanesthetic drugs. }\end{array}$} \\
\hline \multirow{2}{*}{$\begin{array}{l}\text { Mean BP Observation } \\
\text { Baseline and After Intubation }\end{array}$} & \multicolumn{2}{|c|}{$\begin{array}{l}\text { I (Gabapentin) } \\
\quad \mathrm{N}=30\end{array}$} & \multicolumn{2}{|c|}{$\begin{array}{l}\text { II (Placebo) } \\
\quad \mathrm{N}=30\end{array}$} & \multirow{2}{*}{$\begin{array}{l}\text { P-Value for } \\
\text { t-test }\end{array}$} \\
\hline & Mean & $\begin{array}{l}\text { Standard } \\
\text { Deviation }\end{array}$ & Mean & $\begin{array}{l}\text { Standard } \\
\text { Deviation }\end{array}$ & \\
\hline Baseline & 93 & 12 & 97 & 11 & $0.412(P>0.05)$ \\
\hline 1-minute after intubation & 105 & 20 & 112 & 20 & $0.106(P>0.05)$ \\
\hline 2- minute after intubation & 91 & 18 & 103 & 18 & $0.011(\mathrm{P}<0.05)$ \\
\hline 3-minute after intubation & 92 & 16 & 95 & 20 & $0.325(P>0.05)$ \\
\hline 4-minute after intubation & 86 & 12 & 89 & 13 & $0.367(\mathrm{P}>0.05)$ \\
\hline 5-minute after intubation & 80 & 12 & 85 & 11 & $0.065(P>0.05)$ \\
\hline 10-minute after intubation & 79 & 12 & 88 & 13 & $0.01(\mathrm{P}<0.05)$ \\
\hline 15-minute after intubation & 78 & 14 & 87 & 12 & $0.020(\mathrm{P}<0.05)$ \\
\hline
\end{tabular}

\section{DISCUSSION}

Our study result showed that as compared to placebo group there was trends of less cardiovascular response in gabapentin group.

Statistically it was observed that as compared to placebo mean heart rate with Gabapentin was falling at lower side but at 10 and 15 minutes after intubation it was significant. However, it was also significantly low at 1 minute at $\mathrm{P}=0.1$.

Statistical analysis also showed that as compared to placebo the mean systolic blood pressure was at lower side but after intubation at 1,2,10 and 15 minutes it was significant $P=0.05$.
As compared to placebo mean diastolic with gabapentin was generally falling at lower side but at it was significant 3 minute after intubation.

As compared to placebo mean BP with Gabapentin was generally falling at lower side but after intubation at 2, 10 and 15 minutes it was significant $\mathrm{P}=0.05$.

In their study Fassoulaki and colleagues observed the same effect of gabapentin. ${ }^{17}$ They took 46 patients, placebo capsule to the one group and giving $1600 \mathrm{mg}$ of gabapentin to other group, starting the day before surgery at 6 hours interval. They observed the results at 1, 3, 5 and 10 minutes of interval after intubation before and after the anesthetic. Their results were not very 
different from our study and their results showed that systolic blood pressure at 1, 3, 5, and 10 minutes post intubation period was significantly lower. The difference that why in our study at 3, 4 , and 5 minutes interval systolic blood pressure was not significantly low could be explained that in our study the dose of gabapentin used was 800 $\mathrm{mg}$ and given one hour before anesthesia while $1600 \mathrm{mg}$ of gabapentin was used by Fassoulaki and his colleagues and given the drug one day before.

The effect of gabapentin in attenuation of hemodynamic responses tolaryngoscopy and tracheal intubation was evaluated by Shashi Kiran and Deepak Vermal. ${ }^{18}$ A total of one hundred patients were studied. Gabapentin 800 mg were given to patients in group A while placebo capsules were given to group $B$ the night before and on the morning of surgery. At 0, 1, 3, 5 and 10 min after intubation systolic blood pressure was significantly lower in the gabapentin as compared to the control group. At 0, 1, 3, and 5 min after intubation diastolic blood pressure was lower in the gabapentin group. At 0, 1, 3, and 5 min after intubation mean atrial pressure was also lower in the gabapentin group. Because of the use of same strength of gabapentin $800 \mathrm{mg}$ as we used the results were similar in both studies.

Another study comparing the effect of gabapentin on arterial blood pressure and heart rate at after induction and endotracheal intubation was conducted by D. Memis, A. Turan, B. Karamanlioglu, S. Seker and M. Ture. ${ }^{19}$ There was a significant increase in arterial blood pressure and heart rate associated with endotracheal intubation in patients receiving gabapentin 400 mg.

The results showed that 800 of gabapentin which we used in our study was sufficient in attenuating cardiovascular response to tracheal intubation. Dose of $400 \mathrm{mg}$ of gabapentin was not sufficient in this regard.

\section{CONCLUSION}

It was concluded that gabapentin given in a dose of $800 \mathrm{mg}$ orally one hour before the induction of anesthesia showed significantly decrease in cardiovascular response to laryngoscopy and intubation as compared to placebo. Although $1600 \mathrm{mg}$ of gabapentin used in one study by Fassoulaki has shown to be more effective in attenuating cardiovascular response to laryngoscopy and intubation but we did not used this dose because of the general observation that with this much dose there is prolonged postoperative sedation.

Copyright@ 20 Feb, 2020.

\section{REFERENCES}

1. Carrie ES., Peter J. Simpson. Understanding anesthesia: Indications for endotracheal intubation. $4^{\text {th }}$ Ed. Michigan. Heinemann Professional; 2001:213.

2. Kayhan Z, Aldemir D, Mutlu H, Ogus E. Which is responsible for the hemodynamic response due to laryngoscopy and tracheal intubation? Catecholamines, vasopressin or angiotensin? European journal of Anesthesiology. 2005; 22: 780-85.

3. Morgan GE, Mikhail MS, Murray MJ. Clinical anesthesiology: Airway management. $4^{\text {th }}$ Ed. New York. McGraw Hill Companies Inc; 2002:110.

4. Ismail S, Azam SI, Khan FA. Effect of age on hemodynamic response to tracheal intubation. A comparison of young, middle-aged and elderly patients. Anaesth Intensive Care 2002; 30: 608-14.

5. Casati A, Cappelleri G, Fanelli G, Magistris L, Beccaria P, Albertin $A$ et al. The presser response after laryngeal mask or cuffed oropharyngeal airway insertion. Acta Anaesthesiol Scand. 1999; 43:1053-6.

6. Hosten T, Gurkan Y, Ozdamar D, Tekin M, Toker K, Solak M.A. New supraglottic airway device: LMASupreme, comparison with LMA-Proseal. Acta Anaesthesiologica Scandinavica. 2009; 53: 852-7.

7. Bortone L, Ingelmo PM, Ninno G, Tosi M, Caffini L, Trenchi J. Randomized controlled trial comparing the laryngeal tube and the laryngeal mask in pediatric patients. Paediatr Anaesth. 2006; 16:251-7.

8. Theiler LG, Kleine M, Kaiser D, Urwyler N, Luyet C, Vogt A et al. Crossover comparison of the laryngeal mask supreme and the Gel in simulated difficult airway scenario in anesthetized patients. Anesthesiology. 2009; 111:55-62.

9. Koichi T, Yuji M, Osamu K. Tracheal lidocaine attenuates the cardiovascular response to endotracheal intubation. Canadian Journal of Anesthesia. 2001; 48: 732-736. 
10. Kim JT, Shim JK, Kim SH, Ryu HG, Yoon SZ, Jeon YS et al. Remifentanil vs. lignocaine for attenuating the hemodynamic response during rapid sequence induction using propofol. Clin Drug Investing. 2007; 27: 269-77.

11. Figueredo E, Garcia EM. Assessment of the efficacy of esmolol on the hemodynamic changes induced by laryngoscopy and tracheal intubation: A metaanalysis. Acta Anaesthesiol Scand 2001; 45: 1011-22.

12. Ugur B, Ogurlu M, Gezer E, Nuri O, Gursoy F. Effects of esmolol, lidocaine and fentanyl on hemodynamics responses to endotracheal intubation: A comparative study. Clin Drug Investing. 2007; 27:269-77.

13. Kong V, Irwin G. Gabapentin: A multimodal perioperative drug. British Journal of Anaesthesia. 2009; 9:775786.

14. Bazil CW. New antiepileptic drugs. Neurologist. 2002; 8:71-8.
15. Jensen MP, Chiang YK, Wu J. Assessment of pain quality in a clinical trial of gabapentin extended release for postherpetic neuralgia. Clin J Pain. 2009; 25: 286-92.

16. Serpell MG. Gabapentin in neuropathic pain syndromes: A randomized, double-blind, placebocontrolled trial. Pain. 2002; 99:557-66

17. Fassoulaki A, Melemeni A, Paraskeva A, Petropoulos G. Gabapentin attenuates the pressor response to direct laryngoscopy and tracheal intubation. $\mathrm{Br} J$ Anaesth. 2006; 96:769-73.

18. Kiran S, Verma D. Evaluation of gabapentin in attenuating presser response to direct laryngoscopy and tracheal intubation. SAJAA 2008; 14: 43-46.

19. Memis D, Turan A, Karamanlioglu B, Seker S. Ture M. Gabapentin reduces cardiovascular responses to laryngoscopy and tracheal intubation. European Journal of Anesthesiology 2006, 23:8:686-690.

\begin{tabular}{|c|c|c|c|}
\hline \multicolumn{4}{|c|}{ AUTHORSHIP AND CONTRIBUTION DECLARATION } \\
\hline Sr. \# & Author(s) Full Name & Contribution to the paper & Author(s) Signature \\
\hline 1 & Mohsin Riaz Askri & $\begin{array}{l}\text { Concept, Write up, Data } \\
\text { collection. }\end{array}$ & sh E \\
\hline $\begin{array}{l}2 \\
3\end{array}$ & $\begin{array}{l}\text { Shumyala Maqbool } \\
\text { Kausar Abbas Shah }\end{array}$ & $\begin{array}{l}\text { Data collection, Abstract } \\
\text { conclusion, Methodology. } \\
\text { Proof reading and analysis. }\end{array}$ & \\
\hline 4 & Shahbaz Ahmad & $\begin{array}{l}\text { Literature review, Data } \\
\text { analysis and referencing. }\end{array}$ & \\
\hline
\end{tabular}

